\title{
Growth and phytochemical composition of adhatoda zeylanica in response to foliar application of growth hormones and urea
}

\author{
Madhuri H. Tandel ${ }^{1}$, David A. Animasaun ${ }^{1,2^{*}}$, Ramar Krishnamurthy ${ }^{1 *}$ \\ ${ }^{I}$ C. G. Bhakta Institute of Biotechnology, Uka Tarsadia University, Bardoli, Gujarat India \\ ${ }^{2}$ Department of Plant Biology, Faculty of Life Sciences, University of Ilorin, Ilorin, Kwara State, Nigeria \\ *Correspondence author: krishnamurthy@utu.ac.in
}

\begin{abstract}
This study evaluates effects of foliar application of Kinetin, Benzyladenine and urea on growth, phytochemical and quality of active compound vacisine in Adhatoda zeylanica. Five treatments; distilled water $\left(\mathrm{T}_{1}\right)$ which serves as control, $0.1 \%$ urea $+100 \mathrm{ppm}$ kinetin $\left(\mathrm{T}_{2}\right), 0.1 \%$ urea $+100 \mathrm{ppm}$ Benzyladenine $\left(\mathrm{T}_{3}\right), 0.2 \%$ urea +100 ppm kinetin $\left(\mathrm{T}_{4}\right)$ and $0.2 \%$ urea $+100 \mathrm{pm}$ Benzyladenine $\left(\mathrm{T}_{5}\right)$ were applied as foliar spray every four weeks. Growth parameters, phytochemical screening and physicochemical properties of the treated plants were evaluated. Also, bioactive compound vicisine from the leaf extract was characterised and compared with standard using High Performance Thin Layer Chromatography (HPTLC). All the treatments had better growth performances than T1, however, in term of yield, T2 has optimum effect. Phytochemical screening reveal presence of alkaloid, tannin, phenolic compounds, steroids, proteins and carbohydrates. Water and alcohol solubility, $\mathrm{pH}$, and total ash values were enhance by the treatments. HPTLC analysis showed that the leaf extract active compound vicisine had same quality as the market standard. The study concludes that foliar application of growth hormones and urea in combinations and different concentrations could be used to improve growth and phytochemical yield of medicinal plants.
\end{abstract}

Keywords: Adhatoda zeylanica, HPTLC, phytochemical yield, phytohormones, vicisine 


\section{Introduction}

In the recent decades, there have been continuous increase in global demand for plant derived medicine and natural products, so there is a need to ensure abundance of various medicinal plants as well as to guarantee the quality of the herbal and natural products available to the public. Plants chemical constituents varies considerably depending on genetic and environmental factors, methods of cultivation, time of collection and post-harvest processing. This inherent variability in the chemistry may adversely affect the efficacy of medicinal plants. Therefore, it is imperative to ensure that the plants used for food, medicine and natural products are relatively of high quality that gives the desired efficacy (Kandeel, 1991). To meet this requirement it is essential to establish qualitative and quantitative chemo-profiles of the samples. Production of medicinal plants is mainly under the circumstances of sustainable agricultural system. In this system, management of environmental parameters such as nutrient is very critical if the yield of medicinal plants would be maximized (Abd El-Wahab and Mohammed, 2008)

Plants nutritional requirements are obtained from atmosphere, soil, water and organic matter or by application of organic or inorganic fertilizers. Each plant species requires unique minimum nutrient level, below which the plant shows nutrient deficiency symptoms while excessive uptake could result into toxicity. Three most essential elements for plant growth (Nitrogen-N, Phosphorus-P and Potassium-K) has been applied in various proportions to enhance plant health and growth (Hellal et al., 2011; Oyedeji et al., 2014). Also, Urea, which contains $46 \%$ nitrogen, is widely used in the agricultural industry as an animal feed additive and fertilizer. Proper application of urea would results in increased crop yield. Urea can be applied as a foliar spray on crops, such as potatoes, wheat, vegetables and soybeans due to its high water solubility. Foliage application of urea should contain no more than $0.25 \%$ biuret and the quantity of nitrogen applied at one time should not exceed $20 \mathrm{lb}$. of nitrogen per acre (Overdahl et al., 1991; Khalid, 2012)

Plant hormones (also known as phytohormones) are signal molecules produced within the plant, and occur in extremely low concentrations. These chemicals regulates cellular processes in targeted cells locally and in other locations in the plant and are the underlying factors of different plant mechanisms. They also regulates formation of flowers, stems, leaves, and ripening of fruit and controls senescence (Hellal et al., 2011). Benzyl adenine (BA) is a first-generation synthetic cytokinin that elicits plant growth and development responses, setting blossoms and stimulating fruit richness. However, it is an inhibitor of respiratory kinase in plants and therefore increases post-harvest life of vegetables.

The use of organic matters in combination with inorganic fertilizers to optimize nutrient availability to plants is a difficult task as organic materials have variable and complex chemical nature. This requires the understanding and knowledge of the chemical composition, particularly the nutrient content and quality of organic materials and its interaction with inorganic nutrient sources. Studies have compared the yields from a given amount of inorganic fertilizer; an organic material; and their combinations (Khalid, 2012; Oyedeji et al., 2014), the combinations of organic and inorganic nutrient sources have produced higher yields than solely organic or inorganic sources (Shah and Ahmad, 2006). 
Adhatoda zeylanica, is a shrub in the family Acanthaceae well-known to practitioners of Ayurvedic medicine in India. It is commonly called Vasaka (English), Arusa, Baka and Adusa, in Hindi with several other local names among different folks. The plant grows in several regions of India with high distribution in the lower Himalayan regions. The leaves of A. zeylanica have been used extensively in traditional medicine primarily for respiratory disorders. In addition, its utilization as astringent, diuretic and purgative herb is known in India and other countries for several years (Jain, 1981).

Some decades back, the use of different parts of the plant for various diseases treatment have been documented (Gupta and Chopra, 1954). In the recent time, Rastogi (1990) elucidated the extensive use of the plants parts to treat ailments. Furthermore, A. zeylanica has been used in modern and orthodox drug formulation particularly in treatment of bronchitis (Maikhuri and Gangwar, 1993; Kumar et al., 2005). There are reports that some local folks used decoction of the leaves for antenatal and postnatal remedies and as an abortifacient (Nath et al., 1992; Jain et al., 1994). The leaves extract contains pyrroloquinazoline alkaloids, chiefly vasicine and others such as vasicinone, anisotone, vasicoline, adhavasinone which exert effective pharmacological actions (Haq et al., 1967; Chowdhury and Bhattacharyya, 1985).

Considering the potentials and utility of A. zeylanica, improvement in its cultivation and maintenance of quality to meet the industrial and local need is imperative. If its exploitation should be sustained, there is need to enhance the biomass and phytochemical yields of the plant. To this end, the present study aimed at evaluating foliar application of Kinetin and Benzyl adenine growth hormones as well artificial nutrients (urea) on yield and active compound vasicine composition of the plant.

\section{Materials and Methods}

\subsection{Plant material collection and field establishment}

Clones (stem cuttings with three nodes) of Adhatoda zeylanica collected from the Medicinal Garden of Zandu Foundation For Healthcare, Ambach, India were used for vegetative propagation of the plant. The field experiment was conducted at the C. G. Bhakta Institute of Biotechnology, Uka Tarsadia University, Bardoli, India from 2012 -2015. The experiment was laid-out in five (5) treatments with three replicates each in a completely randomized block design with $1 \mathrm{~m} \times 1 \mathrm{~m}$ spacing in-between plants and rows. The first foliar treatment $\left(\mathrm{T}_{1}\right)$ was distilled water spray which also served as the control for the experiment. The second treatment $\left(\mathrm{T}_{2}\right)$ comprised $0.1 \%$ urea +100 ppm kinetin; treatment three $\left(\mathrm{T}_{3}\right)$ was a mixture of 0.1 $\%$ urea +100 ppm Benzyl adenine (BA). Treatment four $\left(\mathrm{T}_{4}\right)$ was a mixture of $0.2 \%$ urea $+100 \mathrm{ppm}$ kinetin while treatment five $\left(\mathrm{T}_{5}\right)$ contained $0.2 \%$ urea +100 pm Benzyl adenine (BA). Hormones and nutrient combination treatments were sprayed on the plant leaves every four weeks. The plant were irrigated to field capacity every week, weeding and other cultural practices were carried out as when due.

\subsection{Growth and yield parameter evaluation}

The plants were evaluated for plant height, number of branches per plant, number of leaves per plant, fresh and dry leaf yield at maturity (36 months after planting)

\subsection{Physicochemical Analysis Leaf extract preparation}

Leaves were collected from the $A$. zeylanica plants treated with different hormones and nutrients for 
extract preparation at maturity in the months of January and July which spanned two different seasons (winter and monsoon). The harvested leaves were thoroughly washed, shade-dried and made into a coarse powder. Leaf extract was prepared using $2 \mathrm{~g}$ of powdered leaf with $50 \mathrm{ml}$ of $95 \%$ ethanol under 80 $\mathrm{KHz}, 45^{\circ} \mathrm{C}$ in ultrasonic extraction device for $30 \mathrm{~min}$, repeated thrice. The extract was collected and filtered and the filtrate dried at $50{ }^{\circ} \mathrm{C}$ under reduced pressure on a rotary evaporator. The dried crude extract was dissolved in $100 \mathrm{ml}$ mobile phases, then filtered through filter paper and a $0.45 \mathrm{~mm}$ membrane filter (Millipore). A commercial product "VASA Churna" which is a fine green powder from A. zeylanica leaves was used as a standard for comparison.

\subsection{Qualitative determination of bioactive compound and Physicochemical Analyses}

Qualitative determinations for the presence of bioactive compounds were carried out using standard analytical grade chemicals from Merck, Germany; Sigma-Aldrich, USA and Loba Chem. India. Saponins, carbohydrate, glycosides, alkaloids, phenolic compound, terpenoids, organic acid and tannin presence was determined by methods described by Sofowora (1993). Loss on drying was determined by placing 3 $\mathrm{g}$ of the prepared material in a dried and tarred flat dish, oven-dried at $100-105{ }^{\circ} \mathrm{C}$ in a desiccator over phosphorus pentoxide under atmospheric pressure and at room temperature. The loss in weight of the air-dried material (loss on drying) was gravimetrically determined. Other physicochemical parameters such as water solubility, alcohol solubility, acid insolubility ash, total ash and $\mathrm{pH}$ of the leaves from different treated A. zeylanica were determined by method of Khandelwal (2008).
The presences of various alkaloids were analyzed using Thin Layer Chromatography (TLC). The samples were spotted individually in TLC plate using toluenemethanol-dioxane-ammonia solvent system in ratio 1:1:2.5:0.5. Vasicine (Purity 99.95 \%) $1 \mathrm{mg}$ dissolved in $1 \mathrm{ml}$ methanol was used as reference solution while Dragendorff's reagent $\left(\mathrm{R}_{\mathrm{f}} ; 0.83\right)$ was used as standard. The procedure was performed as described by $\mathrm{Pu}-$ ratchimani and Jha (2004). Vicisine, the major bioactive constituents of $A$. zeylanica leaves were analyzed using high-performance thin layer chromatography (HPTLC). The HPTLC analysis of the extracts was performed on CAMAG Linomat 5 Automatic "Linomat5 -180733 with $100 \mu \mathrm{L}$ syringe (Hamilton); CAMAG glass twin trough chamber $(20 \times 10 \times 4 \mathrm{~cm})$ as the TLC Chamber and CAMAG TLC Scanner Desitometer linked to winCATS software. The TLC plates were silica gel 60 F254 (0.2 mm thickness) pre-coated (Merck, Germany).

A methanolic solution of Vasicine $(1 \mathrm{mg} / \mathrm{ml})$ was prepared and further diluted to $100 \mu \mathrm{g} / \mathrm{ml}$, the solution was applied on plates at $6 \mathrm{~mm}$ apart and $1 \mathrm{~cm}$ from edge of the plate by CAMAG Linomat 5 automatic sample applicator fitted with $100 \mu$ Hamilton Syringe. Methanolic extracts of five different treated plants were applied to parallel track while the mobile phase; Toluene: Methanol : Dioxane : Ammonia ( $1: 1: 2.5$ : 0.5 ) was poured into the second trough and the plates was left to equilibrate in the chamber for $20 \mathrm{~min}$ at 27 ${ }^{\circ} \mathrm{C}$. The plate was then moved to the second trough containing the mobile phase and developed to a distance of $90 \mathrm{~mm}$. The HPTLC analysis was conducted following the method described by Fan et al. (2006). After development, the plate was removed from the chamber, dried in current of hot air, and scanned at $343 \mathrm{~nm}$, using a deuterium lamp coupled with Camag scanner III densitometer at scanning speed of $20 \mathrm{~mm}$ $\mathrm{s}^{-1}$. The offset was $10 \%$, and the sensitivity (SPAN) was optimized at $20 \mathrm{~min}$. 


\subsection{Data analyses}

The growth and yield data obtained from various treated A. zeylanica were analyzed using one-way analysis of variance (ANOVA) followed by Duncan Multiple Range Test (DMRT) at significant value of $P \leq 0.01$. Peak height and area gotten from HPTLC analysis were integrated and the densitogram obtained by vasicine and extract characterization analyzed with winCATS' software (version 3.17).

\section{Results}

Plant height of $A$. zeylanica in response to different concentrations of the folia applied growth hormones and nutrient was highest $(83.05 \mathrm{~cm})$ in plants treated with $0.2 \%$ urea +100 ppm benzyladenine (T5) which was not statistically different from effect produced by other treatments. However, foliar spray of distilled water (T1) produced least height among all the treatments (Table 1). In term of branches, T5 plants are the most branched with average of 27.45 branches per plant which was significantly higher that other treatments. Although least number of branches was found in $\mathrm{T} 1$ which also serves as control, the effect was not significantly different from those of T2 $(0.1 \%$ urea +100 ppm kinetin), T3 (0.1\% urea +100 ppm benzyladenine) and $\mathrm{T} 4(0.2 \%$ urea $+100 \mathrm{ppm}$ kinetin) Number of leaf per plant was highest in T2, but statistically similar for T1, T4 and T5 with the least in T3. While T5 plants had the highest fresh weight, the least was recorded in $\mathrm{T} 1, \mathrm{~T} 2$ plants had significantly highest dry weight as shown in Table 1.

Table 1. Growth and yield parameters of A. zeylanica treated with foliar applications of different concentrations of plant growth hormones and urea fertiliser.

\begin{tabular}{lllllc}
\hline \multirow{2}{*}{ Characters } & \multicolumn{5}{c}{ Treatments } \\
\cline { 2 - 6 } & \multicolumn{1}{c}{ T1 } & \multicolumn{1}{c}{ T2 } & T3 & T4 & T5 \\
\hline Plant height (cm) & $78.35^{\mathrm{b}}$ & $80.35^{\mathrm{ab}}$ & $80.15^{\mathrm{ab}}$ & $82.10^{\mathrm{ab}}$ & $83.05^{\mathrm{a}}$ \\
No. of Branches/plant & $22.95^{\mathrm{b}}$ & $24.30^{\mathrm{b}}$ & $23.85^{\mathrm{b}}$ & $24.45^{\mathrm{b}}$ & $27.45^{\mathrm{a}}$ \\
No. of Leaves/plant & $124.95^{\mathrm{b}}$ & $146.15^{\mathrm{a}}$ & $121.45^{\mathrm{b}}$ & $128.55^{\mathrm{b}}$ & $126.92^{\mathrm{b}}$ \\
Fresh leaf yield/plant (g) & $246.43^{\mathrm{c}}$ & $260.26^{\mathrm{ab}}$ & $256.25^{\mathrm{ab}}$ & $294.70^{\mathrm{a}}$ & $252.75^{\mathrm{b}}$ \\
Dry leaf yield/plant (g) & $112.15^{\mathrm{b}}$ & $132.05^{\mathrm{a}}$ & $117.64^{\mathrm{b}}$ & $113.55^{\mathrm{b}}$ & $116.15^{\mathrm{b}}$ \\
\hline
\end{tabular}

Keys: $\mathrm{T} 1=$ Distilled water spray; $\mathrm{T} 2=0.1 \%$ urea $+100 \mathrm{ppm}$ kinetin spray; $\mathrm{T} 3=0.1 \%$ urea $+100 \mathrm{ppm}$ Benzyl adenine (BA); 4 $=0.2 \%$ urea $+100 \mathrm{ppm}$ kinetine; $\mathrm{T} 5=0.2 \%$ urea $+100 \mathrm{ppm}$ Benzyl adenine 
The loss on drying weight of the treated A. zeylanicai varied with treatments, although, loss on drying of the samples collected for January and June were similar, however, the former had higher loss on drying than the later (Figure 1). The results of phytochemical screening of the extracts from treated A. zeylanica are presented in Table 2. The methods used showed carbohydrate, proteins, steriod, alkaloid, tannis and phenoloic compounds were present in the extracts which were also present in "VASA" used as the standard for comparison.

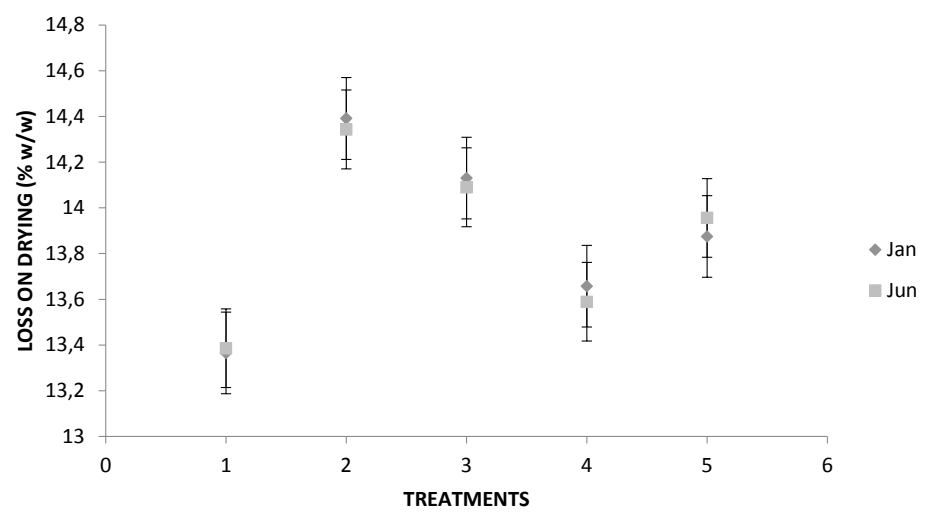

Figure 1. Loss on drying the of $A$. zeylanica leaf treated with different concentrations of folia application of growth hormones (Kinetine and Benzyladenine) and urea.

Keys to treatments $1=\mathrm{T} 1$ (Distilled water spray); $2=\mathrm{T} 2(0.1 \%$ urea $+100 \mathrm{ppm}$ kinetin spray); $3=\mathrm{T} 3(0.1 \%$ urea $+100 \mathrm{ppm}$ Benzyl adenine; $4=\mathrm{T} 4(0.2 \%$ urea $+100 \mathrm{ppm}$ kinetine $) ; 5=\mathrm{T} 5(0.2 \%$ urea $+100 \mathrm{ppm}$ Benzyl adenine $)$

Table 2. Phytochemical screening of the leaf extracts of $A$. zeylanica treated by foliar application of different concentrations of growth hormones and urea fertiliser.

\begin{tabular}{lcccccc}
\hline Phytochemicals & $\mathrm{T}_{1}$ & $\mathrm{~T}_{2}$ & $\mathrm{~T}_{3}$ & $\mathrm{~T}_{4}$ & $\mathrm{~T}_{5}$ & VASA \\
\hline Carbohydrates & + & + & + & + & + & + \\
Proteins & + & + & + & + & + & + \\
Steroids & + & + & + & + & + & + \\
Alkaloids & + & + & + & + & + & + \\
Tannins & + & + & + & + & + & + \\
Phenolic compounds & + & + & + & + & + & + \\
Organic acids & - & - & - & - & - & - \\
Vitamin (Vit. C) & - & - & - & - & - & - \\
\hline
\end{tabular}

$+=$ Present; - = Absent

Keys: $\mathrm{T} 1=$ Distilled water spray; $\mathrm{T} 2=0.1 \%$ urea +100 ppm kinetin spray; $\mathrm{T} 3=0.1 \%$ urea +100 ppm Benzyl adenine $(\mathrm{BA})$; 4 $=0.2 \%$ urea +100 ppm kinetine; $\mathrm{T} 5=0.2 \%$ urea +100 ppm Benzyl adenine 
The results of the physicochemical properties of the treated plant samples collected in Jan and June is shown in Figures 2a-e. Highest loss on drying was recorded in $\mathrm{T} 2$ and the least in $\mathrm{T} 1$ which was also the control. Water solubility trend was similar to loss on drying, T2 had higest water solubility of 24.45 and $24.50 \% \mathrm{w} / \mathrm{w}$ for the collections made in the months of January and June respectively and these values are higher than that of "VASA" (Figure 2b). Similarly, alcohol solubility was highest for T4 among the samples collected in January, while T1 (control) extract had highest alcohol solubilty among the samples collected in June and the two treament produced higher aco- hol solubility than the compared standard "VASA". Treattment T4 produced highest total ash values for both samples collected in January and June, the least ash content $(10.57 \% \mathrm{w} / \mathrm{w})$ was obtained by $\mathrm{T} 5$ which is also lower than the total ash of the standard comparison. The acid insoluble of the extract of the treated plants was in the order; $\mathrm{T} 4>\mathrm{T} 1>\mathrm{T} 3>\mathrm{T} 2>\mathrm{T} 5$ for January collections, whereas, the order was $\mathrm{T} 1>\mathrm{T} 2>\mathrm{T} 3>\mathrm{T} 5>\mathrm{T} 4$ for the June collection (Figure $2 \mathrm{~d})$. Extract obtained from T5 was the most alkaline with $\mathrm{pH}$ values of 7.45 and 7.42 for January and June samples respectively, in contrast, $\mathrm{T} 2$ produced the most acidic extract from the samples (Figure 2e)

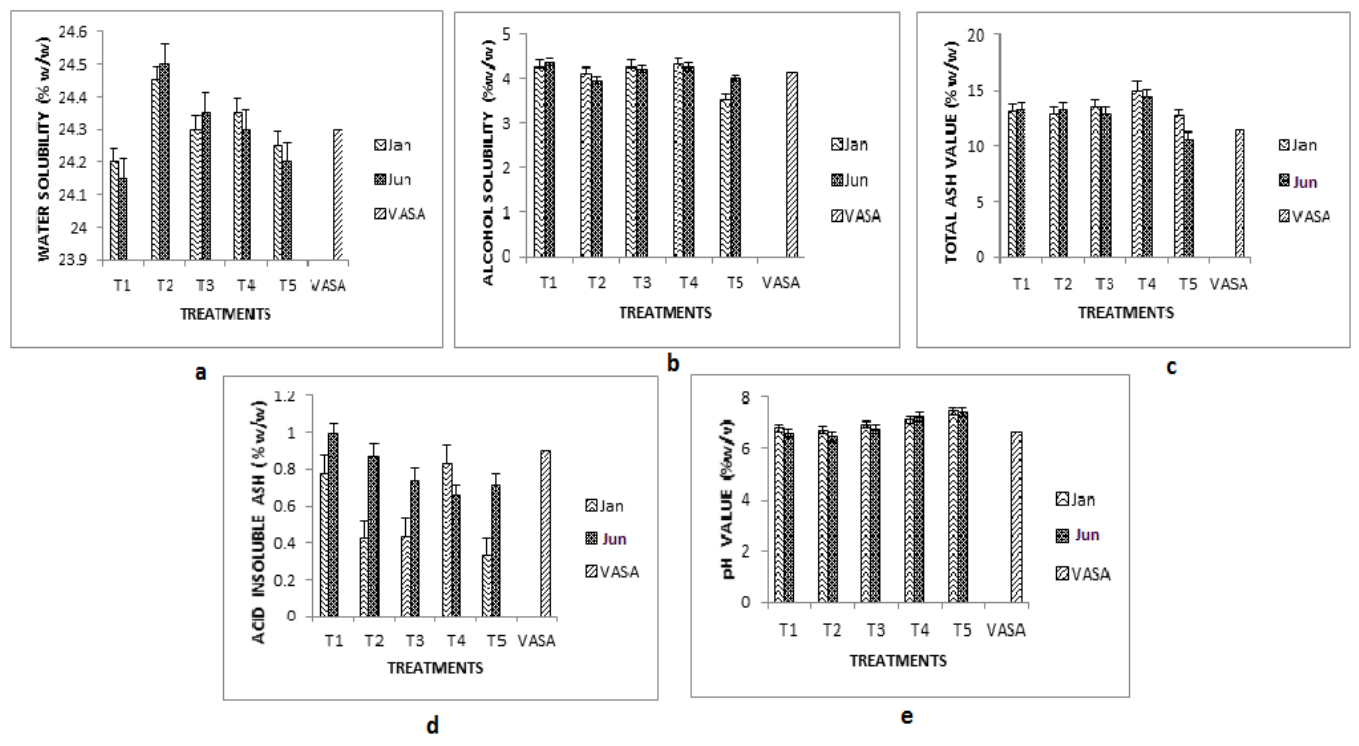

Figure 2. Physicochemical properties of the leaf extracts of $A$. zeylanica treated with folia application of growth hormones and nutrient; (a) water solubility (b) alcohol solubility (c) total ash value (d) acid insoluble ash and, (e) $\mathrm{pH}$ values.

Keys: $\mathrm{T} 1=$ Distilled water spray; $\mathrm{T} 2=0.1 \%$ urea $+100 \mathrm{ppm}$ kinetin spray; $\mathrm{T} 3=0.1 \%$ urea $+100 \mathrm{ppm}$ Benzyl adenine $(\mathrm{BA}) ; \mathrm{T} 4$ $=0.2 \%$ urea $+100 \mathrm{ppm}$ kinetine; $\mathrm{T} 5=0.2 \%$ urea $+100 \mathrm{ppm}$ Benzyl adenine 
The TLC of the active component Visicine was similar for the various hormonal and nutrient treatments applied to A. zeylanica. The January samples $\mathrm{Rf}$ values ranged from 0.84 to 0.82 (Table 3 ), with the least value obtained from $\mathrm{T} 4$, but the trend was different for the June samples, where $\mathrm{T} 5$ had Rf value of 0.84 , $\mathrm{T} 1$ was 0.82 and other treatments had $\mathrm{Rf}$ value of 0.83 which is the same with the standard. The HPTLC chromatogram showed the spectral heights for the visicine obtained from the different treated $A$. zeylanica extracts (Figure 3 ). The peaks were between $33.80-63.60$ and $13.50-46.40 \mathrm{AU}$ for the Visicine present in the January and June samples respectively. Also, the percentage area ranged from $46.27-100 \%$ in January sample, the highest was from T3 while T5 had the least (Table 4). With respect to the standard, only T3 had less percentage area of visicine. Whereas T3 had highest (100\%) percentage area amoung the June samples, T4 (53.51\%) and T5 (46.27\%) are below the percentage area of the used standard.

Table 3. The Thin Layer Chromatography Rf values of active compounds visicine obtained from extracts of $A$. zeylanica treated with different concentrations of hormones and urea fertiliser.

\begin{tabular}{ccc}
\hline \multirow{2}{*}{ Treatments } & January samples & June samples \\
\cline { 2 - 3 } & Visicine Rf value & Visicine Rf values \\
\hline T1 & 0.84 & 0.82 \\
T2 & 0.84 & 0.83 \\
T3 & 0.83 & 0.83 \\
T4 & 0.82 & 0.83 \\
T5 & 0.83 & 0.84 \\
VASA & 0.83 & 0.83 \\
\hline
\end{tabular}

Keys: $\mathrm{T} 1=$ Distilled water spray; $\mathrm{T} 2=0.1 \%$ urea +100 ppm kinetin spray; $\mathrm{T} 3=0.1 \%$ urea $+100 \mathrm{ppm}$ Benzyl adenine (BA); $\mathrm{T} 4$ $=0.2 \%$ urea $+100 \mathrm{ppm}$ kinetine; $\mathrm{T} 5=0.2 \%$ urea $+100 \mathrm{ppm}$ Benzyl adenine

Table 4. HPTLC of bioactive component visicine obtained from extracts of $A$. zeylanica treated with different concentrations of hormones and urea fertiliser

\begin{tabular}{lcccccccc}
\hline Treatment & \multicolumn{4}{c}{ January samples } & \multicolumn{5}{c}{ June samples } \\
\cline { 2 - 8 } & $\mathrm{R}_{\mathrm{f}}$ & Max height (AU) & Area (AU) & \% Area & $\mathrm{R}_{\mathrm{f}}$ & Max height (AU) & Area (AU) & \% Area \\
\hline T1 & 0.84 & 33.80 & 998.20 & 100.00 & 0.83 & 13.50 & 369.10 & 62.24 \\
$\mathrm{~T} 2$ & 0.83 & 58.70 & 1756.10 & 100.00 & 0.84 & 15.30 & 491.20 & 62.06 \\
$\mathrm{~T} 3$ & 0.82 & 59.10 & 1769.00 & 93.87 & 0.83 & 15.70 & 478.70 & 100.00 \\
$\mathrm{~T} 4$ & 0.82 & 51.80 & 1513.80 & 100.00 & 0.82 & 24.50 & 617.10 & 53.51 \\
$\mathrm{~T} 5$ & 0.82 & 63.60 & 1896.80 & 100.00 & 0.84 & 46.40 & 820.00 & 46.27 \\
\hline VASA & 0.83 & 60.90 & 1964.50 & 100.00 & 0.83 & 22.10 & 662.80 & 70.85 \\
STD & 0.83 & 61.00 & 1930.30 & 100.00 & 0.82 & 17.70 & 669.40 & 55.89 \\
\hline
\end{tabular}

Keys: $\mathrm{T} 1=$ Distilled water spray; $\mathrm{T} 2=0.1 \%$ urea $+100 \mathrm{ppm}$ kinetin spray; $\mathrm{T} 3=0.1 \%$ urea $+100 \mathrm{ppm}$ Benzyl adenine $(\mathrm{BA}) ; \mathrm{T} 4$ $=0.2 \%$ urea $+100 \mathrm{ppm}$ kinetine; $\mathrm{T} 5=0.2 \%$ urea $+100 \mathrm{ppm}$ Benzyl adenine 


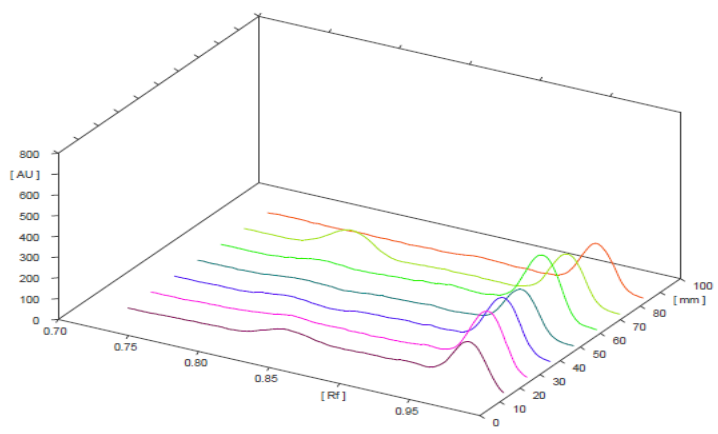

(a)

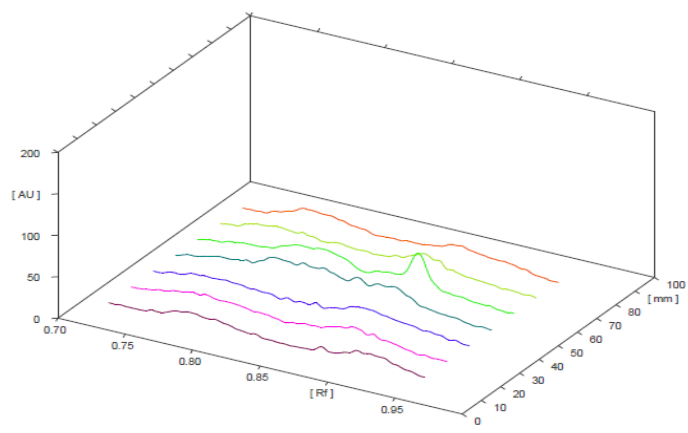

(b)

Figure 3. HPTLC chromatographs of the bioactive component visicine obtained from extracts of A. zeylanica treated with different concentrations of hormones and urea fertiliser. (see supplementary data)

\section{Discussion}

Establishment of the quality control profile of bioactive compounds in plant involved morphological and phytochemical evaluations by standard protocols for the isolation and characterization of the bioactive constituents. This of course is of great important in quality control and medicinal plants utilization, especially for those that could be used as pharmaceutical raw material or use directly by local folks. Therefore, quantitative determination of some phytochemicals and physicochemical parameters are useful for setting standard for crude extract application. Improved growth parameters obtained in this study as a result of foliar application of hormones and nutrients (Urea) is in tandem with Abd El-Wahab and Mohammed (2008), who reported better growth performance of Trachyspermum ammi on applications of some trace elements. Also, similar result was obtained by Khalid (2012) who worked on foliar application of nitrogen 
fertilizer on some members of Apiaceae. While maximum plant growth was obtained with higher combinations of urea and benzyladenine, leave formation was most favoured by less concentration of urea and kinetin foliar application. This implies that combine application of growth hormones and urea would increase growth and biological yield of plant which corroborated the findings of Hellal et al. (2011). This is because nutrient application promotes photosynthesis and transport assimilates of the carbohydrates to the storage organ. Kandeel (1991) demonstrated that using trace elements as foliar application produced significant effect on plant height, fresh weight, dry weight, fruit yield and essential oil content of Petroselinum crispum. Furthermore, Senthil Kumar et al. (2009) revealed that Nitrogen application improves plant height, number of branches, fresh and dry weight of shoot, dry matter production, fresh herb yield and essential oil yield of Artemisia pallens.

Loss on drying of the samples collected in June were different from those collected in January, this may be due to higher moisture content of the later as a result of abundant rainfall and precipitation. Highest water solubility was obtained with $0.1 \%$ urea +100 ppm kinetin, solubility for other treatments were similar to that of the standard control (VASA) while less for plant treated with distilled water. This suggests that treatment concentrations affects water solubility. In contrast, alcohol solubility of the extracts from the two seasons were similar even for the different treatments because solubility was not affected by season and nutrient availability or concentrations. Acid insoluble ash of the samples were less than the VASA, which mean acid insoluble ash was negatively affected by foliar hormonal and nutrient application to A. zeylanica. Nonetheless, since amount of water in a sample would affect the concertation of the hydrogen ions, the $\mathrm{pH}$ of the January samples was slightly higher than those of the June for the treatments due to less moisture content of the former.
The positive effects of foliar applications of growth hormones and urea on A. zeylanica may be due to the important physiological role of the hormones and nutrient in synthesis of the plant phytochemicals through the action of different enzymes activity and protein synthesis. Consequently, it reflected on an increase in quantity and quality of biochemical parameters of the plants. The obtained results are in accordance with those obtained by previous workers in this regard (Randhawa et al., 1996; Silva and Uchida, 2000). In addition, it was demonstrated that Nitrogen base fertilizer caused a significant increase in the vegetative growth, essential oil, fixed oil, total carbohydrates, soluble sugars plants (Zheljazkov and Margina, 1996; Khalid, 2001). Physicochemical constituent such as total ash provides information on the mineral composition and quality of the plant bio-constituents just as the extractive values help to determine the amount of active constituents which can be used as a major tool for obtaining a quality control profile of a medicinal plant (Sharma and Kumar, 2016).

The treatments implication on the $\mathrm{Rf}$ values of the bioactive compound visicine revealed that foliar applications of growth hormones and nutrient treatments did not remarkably affect the quality of the bioactive compound. Although T3 produced same quality of vasicine as the market standard, other treatment are not too deviated in term of quality of the active substance. Thus, as the treatments increase growth and phytochemical yield, it may not significantly affect the quality of the chemical constituents. The quality of bioactive compound obtained in this study concurred with the study of Sarkar et al. (2014).

This study isolated vacisine from leaves of A. Zeylanica and characterized using HPTCL spectra. Although the alkaloid vasicine which is the main active constituent of the plant, however it may be easily oxidized in presence of light and moisture to its more stable form vasicinone which may account for more 
than $30 \%$ of crude extract (Chowdhuri et al., 1987). The spectra of vacisine from HPTLC analysis in this study is similar to those obtained by Suthar et al. (2009). Thus the study revealed that foliar application of the growth hormones and urea though improves biochemical yield, it does not reduces the quality of bioactive compound as the present results agreed with the findings of Srivastava et al. (2001). Therefore, foliar application of growth hormones and nutrition in moderate concentrations could enhance growth, biochemical yield and active compound in A. zeylanica.

\section{Conclusion}

The present study evaluated effects of folia application of plant growth hormones and urea on growth parameters, biochemical yield and purity of the bioactive vacisine from the extract of $A$. zeylanica. The results showed that plant performance with respect to growth and phytochemical yield was enhanced by the treatment without compromising the quality of the major bioactive compound vacisine. In addition, it was revealed that phytochemical constituents of $A$. zeylanica collected in two different seasons differs slightly in phytochemical yield and physicochemical properties. The quality and characteristics of the bioactive compound vicisine from the treated plants are similar with the standard market product. The study concludes that foliar application of phytohormones and nutrient could be used to improve growth and biochemical yield of $A$. zeylanica. Thus providing an improved agricultural practices to increase cultivation and production of medicinal plant.

\section{References}

Abd El- Wahab, A., Mohamed, A. 2008. Effect of some trace elements on growth, yield and chemical constituents of Trachyspermum ammi
L. (Ajowan) plants under sinai conditions. Res. J. Agric. Bio. Sci. 4: 717-724.

Chowdhuri, B.K., Hirani, S.K. 1987. HPLC Study of the Photochemical Oxidation of Vasicine and its analogues. J. Chromatogr. 390: 439-443.

Chowdhury, B.K., Bhattacharyya, P. 1985. A Further Quinazoline Alkaloid from Adhatoda vasica. Phytochemistry 24: 3080-2.

Fan, X.H., Cheng, Y.Y., Ye, Z.L., Lin, R.C., Qian, Z.Z. 2006. Multiple chromatographic fingerprinting and its application to the quality control of herbal medicines. Anal. Chim. Acta. 555: 217-224.

Gupta, K.C., Chopra, I.C. 1954. Anti-tubercular action of Adhatoda vasica (Acanthaceae). Indian J. Exp. Biol. 42: 355-358.

Haq, M.E., Ikram, M., Warsi, S.A. 1967. Chemical Composition of Adhatoda Vasica D - Vasicine, Vasicinine, Beta Sito Sterol, Tri Triacontane Alkaloids. Pakist. J. Scientific and Industrial Res. 10: $224-225$

Hellal, F.A., Mahfouz, S. A., Hassan, F.A.S. 2011. Partial substitution of mineral nitrogen fertilizer by bio-fertilizer on (Anethum graveolens L.) plant. Agri. Biol. J. North Amer. 4: 652-660.

Jain, S.P., Verma, D.M. 1981. Medicinal plants in the folklore of Northeast Haryana. National Academy Science Letters (India). 4: 269-271.

Jain, S.P., Singh, S.C., Puri, H.S. 1994. Medicinal plants of Neterhat, Bibar, India. Inter. J. Pharmacogno. 32: 44-50.

Kandeel, A. 1991. Influence of soil and foliar nutrition on growth and volatile oil content of parsley (Petroselinum crispum Mill). Ann. Agric. Sci. 36: 155-162.

Khalid, K.A. 2001. Physiological studies on the growth and chemical composition of Nigella sativa L. plants. Doctoral thesis, Fac. Agric., AinShams Univ., Cairo, Egypt. 
Khalid, A.K. 2012. Effect of NP and foliar spray on growth and chemical compositions of some medicinal Apiaceae plants grow in arid regions in Egypt. Journal of Soil Science and Plant Nutrition 12: 617-632.

Khandelwal, K.R. 2008. Practical Pharmacognosy, Nirali Prakashan, Pune, 19th edition, 146-148, 149-156 pp.

Kumar, A., Ram, J., Samarth, R.M., Kumar, M. 2005. Modulatory influence of Adhatoda vasica Nees leaf extract against gamma irradiation in Swiss albino mice. Phytomedicine. 12: 285-293.

Maikhuri, R.K., Gangwar, A.K. 1993. Ethnobiological notes on the Khasi and Garo tribes of Meghalaya, Northeast India. Economic Bot. 47: 345-357.

Nath, D., Sethi, N., Singh, R.K., Jain, A.K. 1992. Commonly used Indian abortifacient plants with special reference to their teratologic effects in rats. Journal of Ethnopharmacology. 36: 147-54.

Overdahl, C.J., George, W.R., Harvey, L.M. 1991. Fertilizer Urea. University of Minnesota Extension Service. http://www.extension.umn.edu/distribution/cropsystems/DC0636.html

Oyedeji, S., Animasaun, D.A., Bello, A.A. Agboola, O.O. 2014. Effect of NPK and Poultry Manure on Growth, Yield, and Proximate Composition of Three Amaranths. Journal of Botany, Volume 2014, Article ID 828750, 6 pages, http://dx.doi. org/10.1155/2014/828750.

Shah, Z., Ahmad, M.I. 2006. Effect of integrated use of farm yard manure and urea on yield and nitrogen uptake of wheat. J. Agric. Biol. Sc. 1: 60-65.

Sofowora, A. 1993. Med. plants traditional medicine in Africa. Spectrum Books Ltd., Ibadan, Nigeria, 191-289 pp.

Puratchimani, V., Jha, S. 2004. HPTLC standardization of Gymnema sylvestre R.Br. Using gymnestrogenin as references. Ind. J. Pharm. Sci. 66: 242-244.
Randhawa, G.S., Gill, B.S., Saini, S.S., Singh, J. 1996. Effect of plant spacing and nitrogen levels on the seed yield of dill seed (Anethum graveolens L.). Acta Hort. 426: 623 - 628.

Rastogi, R.P. 1990. Compedium of India medicinal plants. Vol 1. CSIR, New Delhi. 118-122 pp.

Sarkara, C., Bosea, S., Banerjeeb, S. 2014. Evaluation of hepatoprotective activity of vasicinone in mice. Indian Journal of Experimental Biology. 54: 705-711.

Senthil Kumar, T., Swaminathan, V., Kumar, S. 2009. Influence of nitrogen, phosphorus and biofertilizers on growth, yield and essential oil constituents in Raton crop of davana (Artemisia pallens Wall.). Elec. J. Environ. Agric. Food Chem. 8: 86-95.

Sharma, A., Kumar, A. 2016. Pharmacognostic studies on medicinal plants: Justicia adhatoda. World Journal of Pharmaceutical Research. 5: 16741704

Silva, J.A., Uchida, R. S. 2000. Plant nutrient management in Hawaii's soils: approaches for tropical and subtropical agriculture. Honolulu (HI): University of Hawaii. Preface and Introduction, 1-7 pp.

Srivastava, S., Verma, R.K., Gupta, M.M., Singh, S.C., Kumar, S. 2001. HPLC determination of vasicine and vasicinone in Adhatoda vasica with photodiod array detection. J. Liq. Chrom. Rel. Technol. 24: $153-159$.

Suthar, A.C., Katkar, K.V., Patil, P.S., Hamarapurkar, P.D., Mridula, G., Naik, V.R., Mundada, G.R., Chauhan, V.S. 2009. Quantitative estimation of vasicine and vasicinone in Adhatoda vasica by HPTLC. Pharmacy Res. 2: 1899.

Zheljazkov, V., Margina, A. 1996. Effect of nitrogen doses of fertilizer application on quantitative and qualitative characters of mint. Acta Hort. 426: $579-592$. 